\section{Adequacy of prenatal care as a major determinant of folic acid, iron, and vitamin intake during pregnancy}

\author{
Adequação dos cuidados pré-natais como \\ determinante da utilização de ácido fólico, \\ ferro e vitaminas durante a gravidez
}

\author{
1 Faculdade de Medicina, \\ Universidade do Porto, \\ Porto, Portugal. \\ Correspondence \\ $N$. Lunet \\ Serviço de Higiene e \\ Epidemiologia, Faculdade \\ de Medicina, Universidade \\ do Porto. \\ Al. Prof. Hernâni Monteiro, \\ Porto \\ 4200-319, Portugal. \\ nlunet@med.up.pt
}

\begin{abstract}
This study aimed to quantify the association between adequacy of prenatal care and prevalence of folic acid, iron, and multivitamin intake during pregnancy. Data were obtained on socio-demographics, prenatal care, pregnancy complications, and use of vitamin/mineral supplements for 836 women, using a postpartum interview. Associations with the use of vitamin/mineral supplements were quantified with risk ratios $(R R)$, computed by generalized binomial regression. A high proportion of women reported the use of folic acid (81.9\%), iron (55.4\%), and multivitamins (76.2\%) as supplements during pregnancy. Use of supplements was independently associated with adequacy of prenatal care (adequate vs. inadequate: folic acid, $R R=$ 2.28; 95\%CI: 1.58-3.29; iron, $R R=1.99$; 95\% CI: 1.57-2.52, multivitamins, $R R=1.97 ; 95 \% C I$ : 1.54-2.51). Higher schooling was also associated with increased use of folic acid $(R R=1.42$; 95\%CI: 1.18-1.70), but not multivitamins ( $R R=$ 0.87; 95\%CI: 0.77-0.98). Use of folic acid was less prevalent in single women $(R R=0.67 ; 95 \% C I$ : 0.48-0.95) and during unplanned pregnancies $(R R=0.81$; 95\%CI: 0.71-0.92). Adequacy of prenatal care is a major determinant of vitamin/ mineral intake during pregnancy.
\end{abstract}

Folic Acid; Iron; Vitamins; Prenatal Care; Pregnancy

\author{
Nuno Lunet 1 \\ Teresa Rodrigues 1 \\ Sofia Correia ${ }^{1}$ \\ Henrique Barros ${ }^{1}$
}

\section{Introduction}

Obstetric guidelines recommend that all women use folic acid supplements in the periconceptional period to prevent neural tube defects. Prescription of iron for all pregnant women is not a consensus $1,2,3$, since dietary intake may be sufficient to maintain recommended levels 4 . Supplements should be reserved for women with or at high risk of anemia (women from developing countries, multiparous women, or those with multiple gestations or gestational hemorrhage) 2 . The use of other vitamins and mineral supplements is questioned, except for low-income women, those with special diets, or those under treatment with specific drugs 5,6.

Previous studies have quantified the use of vitamins and minerals in pregnancy $1,4,7,8,9,10,11$ $12,13,14,15,16,17,18,19,20,21,22,23,24,25,26,27,28,29,30,31,32$, $33,34,35,36,37,38$, and some have addressed its association with age $11,12,13,30,31,38$, ethnicity $8,12,13,30,33$, education $11,13,18,30,31,36,38$, marital status $11,13,38$, parity $11,13,18,31,38$, and planning of pregnancy $11,18,32,34,38$. However, the effect of prenatal care has often been disregarded $8,11,18,27,29$ or has relied on single measures such as the source of care $4,13,26,30,38$ or simply attendance at prenatal care visits 12,36. Additionally, the influence of prenatal care vitamin/mineral supplementation and its relationship to sociodemographic factors can be expected to vary from country to country, namely concerning 
the presence of financial barriers to prenatal care.

We thus aimed to estimate the prevalence of vitamin/mineral supplement use during pregnancy and assess the role of demographic, social, and obstetric factors in the use of supplements by pregnant women in Portugal, a country where there is universal free access to medical care during pregnancy.

\section{Material and methods}

We conducted a cross-sectional analysis of data collected from 836 participants, previously evaluated as part of a case-control study, which aimed to evaluate risk factors for preterm delivery 39 . Complete information on drug use during pregnancy was obtained for 423 preterm and 413 term mothers consecutively delivered at two major public hospitals in the North of Portugal. Participants were interviewed 24-72 hours after delivery, using a standardized questionnaire. Selfreported information was obtained on maternal socio-demographic characteristics (age, schooling - categorized as elementary or $\leq 4$ years, < secondary, and $\geq$ secondary, and marital status - married or living with a partner vs. other), number of gestations (nulliparous vs. parous), and pregnancy planning (planned vs. unplanned), chronic illnesses (asthma, diabetes, epilepsy, hypertension, and cardiac diseases), and medical complications during pregnancy (genitourinary infection, gestational hypertension, gestational diabetes, preeclampsia, or vaginal bleeding).

Prenatal care was classified according to the Adequacy of Prenatal Care Utilization Index (APNCU Index) 40. This index combines the month of initiation of care and the percentage of recommended visits adjusted for gestational age at initiation of care and gestational age at delivery. The standard used here was the number of prenatal visits recommended in Portugal 41. Inadequate care was defined as initiation of care after the fourth month of gestation or fewer than $50 \%$ of recommended visits.

Data on utilization of vitamins and minerals during pregnancy were obtained through specific questions on the use of folic acid, iron, and multivitamins and an additional open question on any other drugs not specifically mentioned. Information on use of medicines during pregnancy was obtained without reference to the exact trimester.

The association between socio-demographic, obstetric, and prenatal care characteristics and the use of folic acid, iron, and multivitamin supplements was quantified with generalized binomial regression risk ratios (RR) and respective $95 \%$ confidence intervals $(95 \% \mathrm{CI})$, computed using Stata version 9.0 (Stata Corp., College Station, USA).

\section{Results}

Prevalence of use of supplements during pregnancy was $55.4 \%$ for folic acid, $81.9 \%$ for iron, and $76.2 \%$ for multivitamins.

The use of all types of supplements studied was positively associated with the adequacy of prenatal care. Compared to women with inadequate prenatal care, those ranked as adequate were more likely to take folic acid $(\mathrm{RR}=2.28$; 95\%CI: 1.58-3.29), iron (RR = 1.99; 95\%CI: 1.57 $2.52)$, and multivitamins $(\mathrm{RR}=1.97 ; 95 \% \mathrm{CI}$ : 1.54-2.51) (Table 1). The association remained significant and with the same magnitude after adjustment for age, schooling, or income (data not shown).

Folic acid supplements were significantly less frequent among single women $(\mathrm{RR}=0.67 ; 95 \% \mathrm{CI}$ : 0.48-0.95) and those with unplanned pregnancies $(\mathrm{RR}=0.81$; 95\%CI: 0.71-0.92), but increased with schooling (5-11 vs. $\leq 4$ years: $R R=1.23$; 95\%CI: $1.04-1.47$ and $\geq 12$ vs. $\leq 4$ years: $R R=1.42$; 95\%CI: 1.18-1.70). Similar results were observed for iron and multivitamins, but the associations with planning of pregnancy were weaker and non-significant (iron: $\mathrm{RR}=1.00$; 95\%CI: 0.95-1.17 and multivitamins: $\mathrm{RR}=0.97$; 95\%CI: 0.90-1.04), while use of multivitamins was significantly less frequent in women with more education $(\geq 12$ years of formal schooling vs. $\leq 4$ years: $R R=0.87$; 95\%CI: 0.77-0.98) as shown in Table 1.

\section{Discussion}

According to this study, $80 \%$ of pregnant women used iron, slightly more than half received folic acid supplementation, and three-fourths used multivitamins during pregnancy, and adequacy of prenatal care was a strong determinant of the use of these supplements some time during pregnancy.

The retrospective data collection may have underestimated the use of supplements, especially folic acid, which is indicated during the periconceptional period and in the first trimester 42 , while recall of use of medicines during pregnancy is known to be improved by direct questioning about specific drug groups 43 , as occurred in our study for folic acid, iron, and multivitamins. However, the proportions presented in this study describe the use of these supple- 
Use of folic acid, iron, and multivitamins during pregnancy according to socio-demographic status and prenatal care in a sample of Portuguese women *

\begin{tabular}{|c|c|c|c|c|c|c|c|c|c|c|}
\hline & \multirow[t]{3}{*}{$\mathbf{n}$} & \multicolumn{9}{|c|}{ Gestational use of } \\
\hline & & \multicolumn{3}{|c|}{ Folic acid } & \multicolumn{3}{|c|}{ Iron } & \multicolumn{3}{|c|}{ Multivitamins } \\
\hline & & $\%$ & $\begin{array}{c}\text { RR } \\
(95 \% \mathrm{Cl}) * \star\end{array}$ & $\begin{array}{c}\text { RR } \\
(95 \% \mathrm{Cl}) \star \star \star\end{array}$ & $\%$ & $\begin{array}{c}\mathrm{RR} \\
(95 \% \mathrm{Cl}) * \star\end{array}$ & $\begin{array}{c}\text { RR } \\
(95 \% \mathrm{Cl}) \star \star \star\end{array}$ & $\%$ & $\begin{array}{c}\mathrm{RR} \\
(95 \% \mathrm{Cl}) \text { ** }\end{array}$ & $\begin{array}{c}\mathrm{RR} \\
(95 \% \mathrm{Cl}) * \star \star\end{array}$ \\
\hline \multicolumn{11}{|l|}{ Age (years) } \\
\hline$\leq 19$ & 52 & 38.5 & 1.00 & 1.00 & 67.3 & 1.00 & 1.00 & 71.2 & 1.00 & 1.00 \\
\hline $20-34$ & 685 & 56.9 & $\begin{array}{c}1.34 \\
(0.96-1.90)\end{array}$ & $\begin{array}{c}1.34 \\
(0.94-1.90)\end{array}$ & 83.8 & $\begin{array}{c}1.08 \\
(0.93-1.27)\end{array}$ & $\begin{array}{c}1.09 \\
(0.93-1.27)\end{array}$ & 77.5 & $\begin{array}{c}0.97 \\
(0.85-1.11)\end{array}$ & $\begin{array}{c}0.98 \\
(0.86-1.12)\end{array}$ \\
\hline$\geq 35$ & 97 & 54.6 & $\begin{array}{c}1.34 \\
(0.92-1.95)\end{array}$ & $\begin{array}{c}1.39 \\
(0.95-2.03)\end{array}$ & 78.4 & $\begin{array}{c}1.09 \\
(0.92-1.29)\end{array}$ & $\begin{array}{c}1.11 \\
(0.94-1.29)\end{array}$ & 70.1 & $\begin{array}{c}0.90 \\
(0.76-1.08)\end{array}$ & $\begin{array}{c}0.94 \\
(0.79-1.12)\end{array}$ \\
\hline \multicolumn{11}{|c|}{ Schooling (complete years) } \\
\hline$\leq 4$ & 205 & 41.5 & 1.00 & 1.00 & 70.7 & 1.00 & 1.00 & 72.2 & 1.00 & 1.00 \\
\hline $5-11$ & 445 & 56.6 & $\begin{array}{c}1.23 \\
(1.04-1.47)\end{array}$ & $\begin{array}{c}1.26 \\
(1.05-1.50)\end{array}$ & 84.5 & $\begin{array}{c}1.09 \\
(1.00-1.18)\end{array}$ & $\begin{array}{c}1.09 \\
(1.01-1.19)\end{array}$ & 80.4 & $\begin{array}{c}1.01 \\
(0.93-1.10)\end{array}$ & $\begin{array}{c}1.01 \\
(0.93-1.10)\end{array}$ \\
\hline$\geq 12$ & 186 & 67.7 & $\begin{array}{c}1.42 \\
(1.18-1.70)\end{array}$ & $\begin{array}{c}1.43 \\
(1.18-1.72)\end{array}$ & 88.2 & $\begin{array}{c}1.08 \\
(0.99-1.18)\end{array}$ & $\begin{array}{c}1.08 \\
(0.99-1.19)\end{array}$ & 70.4 & $\begin{array}{c}0.87 \\
(0.77-0.98)\end{array}$ & $\begin{array}{c}0.88 \\
(0.78-0.98)\end{array}$ \\
\hline \multicolumn{11}{|l|}{ Marital status } \\
\hline Married & 764 & 57.7 & 1.00 & 1.00 & 84.2 & 1.00 & 1.00 & 77.6 & 1.00 & 1.00 \\
\hline Single & 72 & 30.6 & $\begin{array}{c}0.67 \\
(0.48-0.95)\end{array}$ & $\begin{array}{c}0.71 \\
(0.50-0.99)\end{array}$ & 58.3 & $\begin{array}{c}0.89 \\
(0.76-1.04)\end{array}$ & $\begin{array}{c}0.89 \\
(0.76-1.04)\end{array}$ & 61.1 & $\begin{array}{c}0.94 \\
(0.79-1.10)\end{array}$ & $\begin{array}{c}0.89 \\
(0.75-1.06)\end{array}$ \\
\hline \multicolumn{11}{|l|}{ Paid work } \\
\hline No & 198 & 53.0 & 1.00 & 1.00 & 78.2 & 1.00 & 1.00 & 74.8 & 1.00 & 1.00 \\
\hline Yes & 635 & 56.2 & $\begin{array}{c}1.02 \\
(0.89-1.17)\end{array}$ & $\begin{array}{c}0.95 \\
(0.83-1.09)\end{array}$ & 83.0 & $\begin{array}{c}1.02 \\
(0.95-1.09)\end{array}$ & $\begin{array}{c}1.01 \\
(0.94-1.07)\end{array}$ & 76.7 & $\begin{array}{c}0.98 \\
(0.90-1.06)\end{array}$ & $\begin{array}{c}1.00 \\
(0.92-1.08)\end{array}$ \\
\hline \multicolumn{11}{|l|}{ Previous gestations } \\
\hline No & 411 & 56.0 & 1.00 & 1.00 & 83.4 & 1.00 & 1.00 & 78.4 & 1.00 & 1.00 \\
\hline Yes & 425 & 54.4 & $\begin{array}{c}1.02 \\
(0.91-1.14)\end{array}$ & $\begin{array}{c}1.02 \\
(0.91-1.15)\end{array}$ & 80.5 & $\begin{array}{c}0.99 \\
(0.94-1.05)\end{array}$ & $\begin{array}{c}1.01 \\
(0.96-1.07)\end{array}$ & 74.1 & $\begin{array}{c}0.96 \\
(0.90-1.03)\end{array}$ & $\begin{array}{c}0.98 \\
(0.92-1.06)\end{array}$ \\
\hline \multicolumn{11}{|c|}{ Pregnancy planning } \\
\hline Planned & 498 & 62.9 & 1.00 & 1.00 & 85.9 & 1.00 & 1.00 & 80.1 & 1.00 & 1.00 \\
\hline Unplanned & 327 & 45.0 & $\begin{array}{c}0.81 \\
(0.71-0.92)\end{array}$ & $\begin{array}{c}0.84 \\
(0.74-0.95)\end{array}$ & 75.8 & $\begin{array}{c}1.00 \\
(0.95-1.17)\end{array}$ & $\begin{array}{c}1.01 \\
(0.96-1.07)\end{array}$ & 69.7 & $\begin{array}{c}0.97 \\
(0.90-1.04)\end{array}$ & $\begin{array}{c}0.96 \\
(0.89-1.03)\end{array}$ \\
\hline \multicolumn{11}{|c|}{ Illnesses during pregnancy } \\
\hline No & 300 & 50.0 & 1.00 & 1.00 & 77.3 & 1.00 & 1.00 & 72.3 & 1.00 & 1.00 \\
\hline Yes & 535 & 58.5 & $\begin{array}{c}1.07 \\
(0.94-1.22)\end{array}$ & $\begin{array}{c}1.06 \\
(0.94-1.19)\end{array}$ & 84.5 & $\begin{array}{c}1.00 \\
(0.95-1.06)\end{array}$ & $\begin{array}{c}1.00 \\
(0.94-1.05)\end{array}$ & 78.3 & $\begin{array}{c}1.03 \\
(0.96-1.11)\end{array}$ & $\begin{array}{c}1.03 \\
(0.96-1.11)\end{array}$ \\
\hline \multicolumn{11}{|l|}{ Chronic illnesses } \\
\hline No & 702 & 56.6 & 1.00 & 1.00 & 83.0 & 1.00 & 1.00 & 76.9 & 1.00 & 1.00 \\
\hline Yes & 126 & 50.0 & $\begin{array}{c}0.89 \\
(0.75-1.07)\end{array}$ & $\begin{array}{c}0.87 \\
(0.35-1.04)\end{array}$ & 76.2 & $\begin{array}{c}0.93 \\
(0.85-1.02)\end{array}$ & $\begin{array}{c}0.92 \\
(0.84-1.01)\end{array}$ & 72.2 & $\begin{array}{c}0.98 \\
(0.88-1.08)\end{array}$ & $\begin{array}{c}0.98 \\
(0.89-1.08)\end{array}$ \\
\hline \multicolumn{11}{|c|}{ Gestational age (weeks) } \\
\hline$\geq 37$ & 413 & 56.4 & 1.00 & 1.00 & 84.3 & 1.00 & 1.00 & 78.9 & 1.00 & 1.00 \\
\hline$<37$ & 423 & 54.4 & $\begin{array}{c}1.03 \\
(0.92-1.16)\end{array}$ & $\begin{array}{c}1.05 \\
(0.94-1.17)\end{array}$ & 79.7 & $\begin{array}{c}1.02 \\
(0.96-1.07)\end{array}$ & $\begin{array}{c}1.02 \\
(0.97-1.07)\end{array}$ & 73.5 & $\begin{array}{c}0.98 \\
(0.92-1.05)\end{array}$ & $\begin{array}{c}0.99 \\
(0.92-1.06)\end{array}$ \\
\hline \multicolumn{11}{|c|}{ Adequacy of prenatal care } \\
\hline Inadequate & 93 & 24.7 & 1.00 & 1.00 & 43.0 & 1.00 & 1.00 & 41.9 & 1.00 & 1.00 \\
\hline Intermediate & 116 & 53.4 & $\begin{array}{c}2.16 \\
(1.46-3.20) \#\end{array}$ & $\begin{array}{c}2.10 \\
(1.42-3.09) \# \#\end{array}$ & 82.8 & $\begin{array}{c}1.92 \\
(1.50-2.47) \#\end{array}$ & $\begin{array}{c}1.86 \\
(1.46-2.38) \#\end{array}$ & 76.7 & $\begin{array}{c}1.83 \\
(1.41-2.37) \#\end{array}$ & $\begin{array}{c}1.88 \\
(1.44-2.44)\end{array}$ \\
\hline Adequate & 361 & 56.5 & $\begin{array}{c}2.28 \\
(1.58-3.29) \#\end{array}$ & $\begin{array}{c}2.06 \\
(1.43-2.97) \# \#\end{array}$ & 85.6 & $\begin{array}{c}1.99 \\
(1.57-2.52) \#\end{array}$ & $\begin{array}{c}1.90 \\
(1.50-2.40) \# \#\end{array}$ & 82.6 & $\begin{array}{c}1.97 \\
(1.54-2.51) \#\end{array}$ & $\begin{array}{c}2.02 \\
(1.58-2.59)\end{array}$ \\
\hline Adequate plus & 256 & 67.6 & $\begin{array}{c}2.73 \\
(1.90-3.93) \#\end{array}$ & $\begin{array}{c}2.41 \\
(1.67-3.47) \# \#\end{array}$ & 91.0 & $\begin{array}{c}2.12 \\
(1.67-2.68) \#\end{array}$ & $\begin{array}{c}2.01 \\
(1.59-2.54) \# \#\end{array}$ & 80.5 & $\begin{array}{c}1.92 \\
(1.50-2.46) \#\end{array}$ & $\begin{array}{c}2.00 \\
(1.55-2.57)\end{array}$ \\
\hline
\end{tabular}

* The sum of participants in each category may be lower then 836 due to missing data;

** Adjusted for prenatal care adequacy;

*** Adjusted for prenatal care adequacy, age, and schooling;

\# Crude RR estimate;

\#\# Adjusted for age and schooling. 
ments any time during pregnancy, regardless of dosage and duration of exposure, and no conclusions can be drawn about the proportion of women correctly using supplements regarding timing, dosage, or adherence to prescription regimens.

Our study included an over-sampling of mothers of preterm babies. However, this is not expected to compromise the validity of our estimates, since no significant association was found between the use of vitamin/mineral supplements and preterm status.

Wide variation is observed between countries in the proportion of women taking vitamin or mineral supplements during pregnancy, but such use in different populations cannot be directly compared, because the methods for evaluating exposure differ considerably among studies. Some have been based on institutional databases 8,12,13,23,27,29,37 and have therefore considered only the prescribed vitamins/minerals, not reflecting the real intake. When information was obtained by interview, the moment of data collection was different and varied from prenatal visits $1,7,10,15,16,17,18,19,21,22,25,26,31,34,35$, $36,38,44,45$ until two months after childbirth 9,11,14, 20,24,30,33,46,47.

Some studies have considered exposures during the entire pregnancy, without differentiating between trimesters $1,4,7,8,9,10,11,12,13,19,20,23,24,27,33$, $35,37,38,44,45,46$, some have distinguished between exposure in the first, second, and third trimesters 14,15,22,26,29,30,31,36,47 , and others have included preconceptional use $15,16,17,18,21,38$. The drug groups evaluated and the nomenclature used for characterizing them have also varied across studies, some considering each group separately (folic acid, iron, and vitamins) 8,12,15,16,17,18,21,22,23, $24,28,30,31,34,36,38,44,45$, others in association (e.g.: antianemics, vitamins, and/or antianemics) 1,10 , $13,20,25,27,33,35,47$, or both $4,7,9,11,14,19,26,29,37$.

Despite methodological differences, our study and most others performed in other population groups showed that age (20-34 years) $13,30,32$, more schooling $11,13,18,30,31,32,38$, and planning of pregnancy 18,32,34 were associated with higher prevalence of vitamin/mineral use.

In this sample of Portuguese women, schooling was positively associated with use of folic acid and iron, but not with multivitamins, which were taken more frequently by less educated women. This distribution in the prevalence of use of supplements provides evidence of social inequity, since it probably reflects the ability of better-educated women to make more appropriate health choices: the use of folic acid and iron during pregnancy is frequently recommended and has well-recognized effects, but the same does not apply to multivitamins, unnecessary in most pregnancies. No significant association was observed between having paid work and the use of supplements, suggesting that financial constraints are not as important as education in determining the use of folic acid and iron.

The observation of less frequent supplement use in women with unplanned pregnancies suggests that timing of prenatal care and maternal attitudes toward pregnancy may compromise the ideal scheduling of and compliance with prescribed vitamins and minerals. This effect was seen more clearly for folic acid, probably because it should be used even before conception and is therefore more influenced by pregnancy planning.

Previous research has shown that women attending prenatal care receive supplements more frequently 13 . Our study uses a more comprehensive measure of prenatal care adequacy that combines independent assessment of the timing of prenatal care initiation and the frequency of visits received after initiation ${ }^{40}$, strengthening the role of prenatal care adequacy as a determinant for the use of supplements.

The association between other socio-demographic and obstetric factors and less frequent use of supplements during pregnancy is independent from the adequacy of prenatal care utilization and further reflects maternal attitudes towards pregnancy, social inequity, and failure of primary care providers to promote maternal health. However, we cannot rule out the hypothesis that these results are confounded by other prenatal care characteristics such as adequacy of prenatal care content.

Public health strategies to improve the correct use of vitamins and minerals during pregnancy should include the promotion of pregnancy planning and maternal recognition of the importance of supplements, especially early use of folic acid. 


\section{Resumo}

Quantificar a associação entre a adequação dos cuidados pré-natais e a prevalência de utilização de ácido fólico, ferro e vitaminas durante a gravidez. Após o parto, 836 mulheres foram questionadas relativamente a características sócio-demográficas, utilização dos cuidados pré-natais, complicações durante a gravidez e utilização de suplementos vitamínicos/minerais. A associação entre as variáveis foi quantificada por meio de riscos relativos (RR) calculados por regressão binomial generalizada. Uma elevada proporção de mulheres reportou ter tomado ácido fólico (81,9\%), ferro $(55,4 \%)$ e multivitaminas $(76,2 \%)$ durante a gravidez. A utilização de suplementos esteve independentemente associada à adequação dos cuidados pré-natais (adequado vs. inadequado: ácido fólico, $R R=2,28$; IC95\%: 1,58-3,29; ferro, $R R=1$,99; IC95\%: 1,57-2,52; multivitaminas, $R R=1$,97; IC95\%: 1,54-2,51). O elevado nível de escolaridade associou-se ao uso de ácido fólico ( $R R=1,42$; IC95\%: 1,18-1,70), mas não de multivitaminas ( $R R=0$,87; IC95\%: 0,77-0,98). A utilização de ácido fólico foi menos prevalente em mulheres que viviam sozinhas ( $R R=0,67$; IC95\%: 0,48-0,95) e cuja gravidez não foi planeada (RR = 0,81; IC95\%: 0,71-0,92). A adequação dos cuidados pré-natais é um determinante importante da utilização de vitaminas/minerais durante a gravidez.

Ácido Fólico; Ferro; Vitaminas; Cuidado Pré-Natal; Gravidez

\section{References}

1. Mengue SS, Schenkel EP, Duncan BB, Schmidt MI Uso de medicamentos por gestantes em seis cidades brasileiras. Rev Saúde Pública 2001; 35:415-20.

2. Favier M, Hininger-Favier I. Faut-il supplémenter en fer les femmes enceintes? Gynecol Obstet Fertil 2004; 32:245-50.

3. Ziaei S, Norrozi M, Faghihzadeh S, Jafarbegloo E. A randomised placebo-controlled trial to determine the effect of iron supplementation on pregnancy outcome in pregnant women with haemoglobin > or $=13.2 \mathrm{~g} / \mathrm{dl}$. BJOG 2007; 114:684-8.

4. Carmo TA, Nitrini SMOO. Prescrições de medicamentos para gestantes: um estudo farmacoepidemiológico. Cad Saúde Pública 2004; 20:1004-13.

5. Lumley J, Watson L, Watson M, Bower C. Periconceptional supplementation with folate and/or multivitamins for preventing neural tube defects. In: The Cochrane Database Systematic Reviews, Issue $3,2001$.

6. Drife J, MacNab G. Prescribing in pregnancy: mineral and vitamin supplements. Clin Obstet Gynaecol 1986; 13:253-67.

7. Hartwig H, Rohloff P, Huller H, Amon I. Drugs in pregnancy - a prospective study. Int J Biol Res Pregnancy 1982; 3:51-5.

\section{Contributors}

$\mathrm{N}$. Lunet contributed to the data analysis and interpretation and wrote the first version of the manuscript. $\mathrm{T}$. Rodrigues contributed to the study conception and design and revision of the manuscript. S. Correia contributed to the data analysis and revision of the manuscript. H. Barros contributed to the study conception and design and critically revised the manuscript for intellectual content. All the authors approved the final version of the manuscript for publication.

\section{Acknowledgements}

The authors gratefully acknowledge grants from the Commission for the Promotion of Health Care Research, Ministry of Health of Portugal (155/95), and the Foundation for Science and Technology (SFRH/ $\mathrm{BD} / 3293 / 2000)$
8. Piper JM, Baum C, Kennedy DL. Prescription drug use before and during pregnancy in a Medicaid population. Am J Obstet Gynecol 1987; 157: 148-56.

9. Medication during pregnancy: an intercontinental cooperative study. Collaborative Group on Drug Use in Pregnancy (C.G.D.U.P.). Int J Gynaecol Obstet 1992; 39:185-96.

10. Rizk MA, Abdel-Aziz F, Ashmawy AA, Mahmoud AA, Abuzeid TM. Knowledge and practices of pregnant women in relation to the intake of drugs during pregnancy. J Egypt Public Health Assoc 1993; 68:567-91.

11. Bonassi S, Magnani M, Calvi A, Repetto E, Puglisi P, Pantarotto F, et al. Factors related to drug consumption during pregnancy. Acta Obstet Gynecol Scand 1994; 73:535-40.

12. Timbo B, Altekruse S, Hyman F, Klontz K, Tollefson L. Vitamin and mineral supplementation during pregnancy. Mil Med 1994; 159:654-8.

13. Yu SM, Keppel KG, Singh GK, Kessel W. Preconceptional and prenatal multivitamin-mineral supplement use in the 1988 National Maternal and Infant Health Survey. Am J Public Health 1996; 86:240-2. 
14. Splinter MY, Sagraves R, Nightengale B, Rayburn WF. Prenatal use of medications by women giving birth at a university hospital. South Med J 1997; 90:498-502.

15. de Jong-van den Berg LT, de Walle HE, van der Palde Bruin KM, Buitendijk SE, Cornel MC. Increasing awareness of and behaviour towards periconceptional folic acid consumption in The Netherlands from 1994 to 1995. Eur J Clin Pharmacol 1998; 54:329-31.

16. Wild J, Sutcliffe M, Schorah CJ, Levene MI. Prevention of neural-tube defects. Lancet 1997; 350:30-1.

17. McDonnell R, Johnson Z, Doyle A, Sayers G. Determinants of folic acid knowledge and use among antenatal women. J Public Health Med 1999; 21:145-9.

18. Schader I, Corwin P. How many pregnant women in Christchurch are using folic acid supplements in early pregnancy? N Z Med J 1999; 112:463-5.

19. Damase-Michel C, Lapeyre-Mestre M, Moly C, Fournie A, Montastruc JL. Consommation de médicaments pendant la grossesse: enquête auprès de 250 femmes en consultation dans un Centre Hospitalier Universitaire. J Gynecol Obstet Biol Reprod (Paris) 2000; 29:77-85.

20. Donati S, Baglio G, Spinelli A, Grandolfo ME. Drug use in pregnancy among Italian women. Eur J Clin Pharmacol 2000; 56:323-8.

21. Gharoro EP, Igbafe AA. Pattern of drug use amongst antenatal patients in Benin City, Nigeria. Med Sci Monit 2000; 6:84-7.

22. Henry A, Crowther C. Patterns of medication use during and prior to pregnancy: the MAP study. Aust N Z J Obstet Gynaecol 2000; 40:165-72.

23. Lacroix I, Damase-Michel C, Lapeyre-Mestre M, Montastruc JL. Prescription of drugs during pregnancy in France. Lancet 2000; 356:1735-6.

24. Sabo A, Stanulovic M, Jakovljevic V, Grujic Z. Collaborative study on drug use in pregnancy: the results of the follow-up 10 years after (Novi Sad Centre). Pharmacoepidemiol Drug Saf 2001; 10: 229-35.

25. Maats FH, Crowther CA. Patterns of vitamin, mineral and herbal supplement use prior to and during pregnancy. Aust N Z J Obstet Gynaecol 2002; 42:494-6.

26. Glover DD, Amonkar M, Rybeck BF, Tracy TS. Prescription, over-the-counter, and herbal medicine use in a rural obstetric population. Am J Obstet Gynecol 2003; 188:1039-45.

27. Andrade SE, Gurwitz JH, Davis RL, Chan KA, Finkelstein JA, Fortman K, et al. Prescription drug use in pregnancy. Am J Obstet Gynecol 2004; 191:398-407.

28. Kaim I, Penar A, Sochacka-Tatara E, Galas A, Jedrychowski W. Farmakologiczna suplementacja witaminami i skladnikami mineralnymi w okresie ciqay. Badania epidemiologiczne w Krakowie. Przegl Lek 2004; 61:776-9.

29. Schirm E, MeijerWM, Tobi H, de Jong-van den Berg LT. Drug use by pregnant women and comparable non-pregnant women in the Netherlands with reference to the Australian classification system. Eur J Obstet Gynecol Reprod Biol 2004; 114:182-8.
30. Amitai Y, Fisher N, Haringman M, Meiraz H, Baram $\mathrm{N}$, Leventhal A. Increased awareness, knowledge and utilization of preconceptional folic acid in Israel following a national campaign. Prev Med 2004; 39:731-7.

31. Bener A, Al Maadid MG, Al-Bast DA, Al-Marri S. Maternal knowledge, attitude and practice on folic acid intake among Arabian Qatari women. Reprod Toxicol 2006; 21:21-5.

32. de Jong-Van den Berg LT, Hernandez-Diaz S, Werler MM, Louik C, Mitchell AA. Trends and predictors of folic acid awareness and periconceptional use in pregnant women. Am J Obstet Gynecol 2005; 192:121-8.

33. Checa MA, Peiro R, Pascual J, Carreras R. Drug intake behaviour of immigrants during pregnancy. Eur J Obstet Gynecol Reprod Biol 2005; 121:38-45.

34. Gjergja R, Stipoljev F, Hafner T, Tezak N, LuzarStiffler V. Knowledge and use of folic acid in Croatian pregnant women: a need for health care education initiative. Reprod Toxicol 2006; 21:16-20.

35. Mengue SS, Schenkel EP, Schmidt MI, Duncan BB. Fatores associados ao uso de medicamentos durante a gestação em seis cidades brasileiras. Cad Saúde Pública 2004; 20:1602-8.

36. Sharma R, Kapoor B, Verma U. Drug utilization pattern during pregnancy in North India. Indian J Med Sci 2006; 60:277-87.

37. Hardy JR, Leaderer BP, Holford TR, Hall GC, Bracken MB. Safety of medications prescribed before and during early pregnancy in a cohort of 81,975 mothers from the UK General Practice Research Database. Pharmacoepidemiol Drug Saf 2006; 15:555-64.

38. Nawapun K, Phupong V. Awareness of the benefits of folic acid and prevalence of the use of folic acid supplements to prevent neural tube defects among Thai women. Arch Gynecol Obstet 2007; 276:53-7.

39. Rodrigues T, Barros H. Factores de risco para trabalho de parto pré-termo. Acta Med Port 1998; 11:901-5.

40. Kotelchuck M. An evaluation of the Kessner Adequacy of Prenatal Care Index and a proposed Adequacy of Prenatal Care Utilization Index. Am J Public Health 1994; 84:1414-20.

41. Barros H, Tavares M. Prenatal care use, perinatal and infant mortality in Portugal. An area level analysis. Arch Public Health 1998; 56:263-73.

42. Divisão de Saúde Materna, Infantil e dos Adolescentes, Direcção Geral de Saúde. Prestação de cuidados pré-concepcionais. Porto: Direcção Geral de Saúde; 2006.

43. Mitchell AA, Cottler LB, Shapiro S. Effect of questionnaire design on recall of drug exposure in pregnancy. Am J Epidemiol 1986; 123:670-6.

44. Villanueva ELA, Martinez Ayala H, García-Lara E. Consumo de fármacos en el embarazo. Ginecol Obstet Mex 1998; 66:423-7.

45. Estudio multicéntrico sobre el uso de medicamentos durante el embarazo en España (IV). Los fármacos utilizados durante la lactancia. Grupo de Trabajo DUP España. Med Clin (Barc) 1992; 98:726-30. 
46. Gomes KRO, Moron AF, Silva RS, Siqueira AAF. Prevalência do uso de medicamentos na gravidez e relações com as características maternas. Rev Saúde Pública 1999; 33:246-54.
47. Fonseca MRCC, Fonseca E, Bergsten-Mendes G. Prevalência do uso de medicamentos na gravidez: uma abordagem farmacoepidemiológica. Rev Saúde Pública 2002; 36:205-12.

Submitted on $20 /$ Jun/2007

Final version resubmitted on $03 /$ Oct $/ 2007$

Approved on 08/Oct/2007 